Article

\title{
Korean EFL Students Building and Sustaining New Perspectives through Global Literary Texts
}

\author{
Jungyin Kim
}

Citation: Kim, J. Korean EFL Students Building and Sustaining New Perspectives through Global Literary Texts. Sustainability 2022, 14, 1372. https://doi.org/10.3390/ su14031372

Academic Editors: Xuesong (Andy) Gao and Mairin Hennebry-Leung

Received: 31 December 2021 Accepted: 24 January 2022

Published: 25 January 2022

Publisher's Note: MDPI stays neutral with regard to jurisdictional claims in published maps and institutional affiliations.

Copyright: (C) 2022 by the author. Licensee MDPI, Basel, Switzerland. This article is an open access article distributed under the terms and conditions of the Creative Commons Attribution (CC BY) license (https:// creativecommons.org/licenses/by/ $4.0 /)$.
Department of English Education, Jeonbuk National University, 567 Baekje-daero, Deokjin-gu, Jeonju-si 54896, Korea; luvjanny07@jbnu.ac.kr

\begin{abstract}
Using a qualitative approach, this study examines ways in which reading global literary texts and communicating with native English-speaking teachers informed a group of Korean university students' English language learning and intercultural awareness. The students chose the pre-selected illustrative books, created short video clips, produced electronic books, prepared power point presentations, participated in creative writing sessions, and engaged in small group talk. The main data in this study include English group discussions from the Korean students, observation notes of the students' group discussion and presentations, samples of the students' work, and individual interviews regarding the students' perception of their participation with extensive learning through encounters with cross-national discussions and global literary texts. Findings showed that the students were able to gain and sustain knowledge about and respect for various cultures and cultivate a critical understanding of and appreciation for ways local experiences can be impacted by broader global patterns, and vice versa. Reading global illustrative texts and participating in discussion about the texts helped the students in critically reflecting on their own cultures and those of others. The students further gained a deeper interest in global literary texts and developed their English language skills by communicating with native English-speaking teachers. Pedagogical implications for language and literacy educators are provided.
\end{abstract}

Keywords: cross-cultural awareness; English as a foreign language; global texts; reader responsibility

\section{Introduction}

More than half the people in South Korea (henceforth, Korea) have learned and continue to learn English as a foreign language. Based on Korea's educational curriculum, the English language is required beginning from the third grade and beyond, including undergraduate and graduate programs (Korean Ministry of Education [1]). While the English language is not a compulsory subject until the third grade, students take highstakes English exams through private institutions and pursue postsecondary-level English proficiency exams at an early age. While a number of students consider English as a crucial skill when preparing for their careers, there is a lack of opportunity for writing and speaking (Lee and Villacorta [2]). Korean students listen to, systematically repeat, receive, and retain information delivered by their teachers. In a similar vein, teachers emphasize drill and practice, rote memorization, and exam-focused skills. Rarely do students recreate ideas, think in a critical manner, or unravel social realities (Freire [3]), and informative reading takes precedence over creative reading for many students (Rosenblatt [4]). In Korea, English learning is often more about learning new vocabulary, idiomatic expressions, and interpretation of texts for academic purposes.

In recent years, Korean scholars have advocated task-based language instruction (Kang [5]), content-based teaching (Kim [6]), and shifting the instructional goal from communicative skills to multi- and intercultural skills (Peck and Yates [7]). With the current 7 th curriculum standard revised by the Korean Ministry of Education, instructions are more focused on task-based learning, student-focused instruction, and communicative learning 
through authentic resources (Kim, Jung and Tracy-Ventura [8]). However, such colossal change requires time. There may be a few programs in innovative areas that uphold a progressive educational program; however, the great majority of disciplinary areas often do not meet the above criteria; thus, change needs to take place.

This research draws on and adds to the ways in which Korea has adopted such progressive measures. The goal of this research was to explore how learners of English respond to global illustrative books and extend their communication with native Englishspeaking teachers. The study also considers the pedagogical implications for English literacy and language educators.

The following research question guided this study:

- Through global literary texts and cultural discussion about these texts, how do students of English learn culture and language?

Global literary texts in this study refer to illustrative books chosen by native Englishspeaking teachers from the United States. While the researcher worked with Korean university students, this research may serve as an example for literacy educators at various grade levels. This study begins with an overview of the conceptual framework and research related to the current topic. Thereafter, the context, research design, and data collection and analysis are discussed. This is followed by the study's findings, conclusion, and discussion of implications for classroom practice.

\section{Literature Review}

\subsection{Global Literary Texts}

Evans and Wilson [9] used global literary texts to refer to "any text situated in a global context beyond the reader's own global setting" (p. 56). The researcher adopted this broad description of global texts on the basis of the readers' own cultural settings and the ways the readers make sense of them. Global and multicultural literary texts present readers with a mirror to portray their cultures and with opportunities to learn about different cultures (Flynn [10]). Readers can frame their intercultural knowledge and appreciation through literary texts and learn to become global citizens (Short and Thomas [11]).

Learners of English in a number of Asian countries have been introduced to global literary texts. Researchers (Hong [12], Huang [13] and Mo and Hwang [14]) discovered that these texts assisted in cultivating students' critical awareness, reconstructing their intercultural viewpoints, improving their language abilities, and developing global citizenship.

\subsection{Intercultural Appreciation}

Culture is influential, dynamic, and an integral part of our lives. Otten [15] pointed out that a small part of culture lies in perception, such as the perception of literary works, lyrics, businesses, and sports; a huge component is derives from perception, such as ideas of fairness or beauty, models for regulating youth education, and methods of solving problems. Otten [15] noted that intercultural education occurs along a continuity from ethnocentrism to perception, knowledge, acknowledgement and appreciation, transformation, and ultimately intercultural competency. Intercultural education goes beyond the acquisition of knowledge; it is about building new perspectives and understanding.

A framework for an intercultural course of study involves multicultural studies, cultural identities, exploration of global topics, and consolidation of intercultural viewpoints (RodrÃ-guez and Puyal [16]). It specifically promotes inquiries from a critical standpoint. Heggerness [17] investigated youth talk in inquiry-focused literature groups and discovered that youth's intercultural awareness emphasizes viewpoints, knowledge, and response. Functioning as a gateway, global literary texts assist in building learners' social networks and stances, broadening their thinking, challenging stereotypes, seeking cultural identities, taking basic measures towards intercultural awareness, and carrying out critical inquiries concerning global matters (Heggerness [17]). 


\subsection{Accountability of the Reader}

Reading is a process that is transactive in nature (Briceño and Klein [18]). According to Rosenblatt [4], meaning is construed through reader-text transactions. Based on the reader's background knowledge, experience, and purpose, the reader moves along a continuum from informative reading to aesthetic reading (experiencing the events). As readers learn to read in a second language, they expand upon their culture and native language, current experience and knowledge, and funds of knowledge in a given context (Yol and Yoon [19]).

When responding to global literary texts, it is important for readers to acknowledge various viewpoints, maintain an open mind about texts, recognize that a single literary work may not symbolize a whole culture, and identify the limits of the readers' knowledge (Yokota and Teale [20]). Readers also need to understand and read about the world (Heath [21]), critically rethink their responses to texts, and ask critical questions about texts. Readers create symbols to build knowledge and recreate to challenge and transform their points of views (Comber and Nixon [22]).

Yoon [23] suggested a critical global literacy pedagogical framework that builds on the frameworks of global and critical literacies. This current perspective builds global understandings, encourages socio-political movements on global and intercultural topics, leads to social networks from individual levels to a global level, and analyzes and assesses literary works from global and intercultural viewpoints. In an earlier study, Dasli [24] indicated the significance of developing and sustaining authentic educational experiences for multilingual and bilingual learners, assisting learners to become users of language from a critical standpoint, and addressing and sustaining intercultural competency as a critical process. In their multi-literacy and multi-language framework, Cope and Kalantzis [25] emphasized the importance of sustaining critical engagement in learning language. Noting the influence of language skills on critical thinking, Floyd [26] indicated the importance of teaching bilingual learners to convey critical ideas in a second language.

The researcher acknowledges that learners proactively self-create their understandings and responses, and rely on their current knowledge to build new knowledge (Hedgcock and Ferris [27]). Employing socio-cultural theories of reading and learning (Larson and Marsh [28], Vygotsky [29]), the current study positions learners within a cross-cultural learning context.

\section{Methods}

\subsection{Context}

At a public university in the United States, the researcher worked as teaching assistant for a graduate course for pre-service teachers on literacy and multicultural texts. Six literacy pre-service teachers registered for the course. The pre-service teachers chose literary texts for a large group of Korean students in Korea. The teachers also read and conversed about the texts among themselves. Later in this current study, the teachers responded to the Korean students' questions, raised additional questions based on the students' interaction, and offered feedback on student projects.

The current study's research site was a small teaching college in Korea located in a suburban area with approximately 3309 full-time undergraduate students. Among the current Korean participants in this study, more than half $(68 \%)$ had future goals of becoming elementary school teachers. The current study was conducted in a prerequisite threecredit reading and writing elective course for future teachers. The course was conducted in English and emphasized the improvement of the students' basic English skills, such as speaking, reading, writing, listening, and reading comprehension. The purposes of the course were to assist the students in becoming independent learners, to strengthen and sustain their awareness of various cultures, and to enhance their proficiency in the English language.

The researcher met with the course instructor, Dr. Yoo (a pseudonym) and 29 Korean students (all their names are pseudonyms), twice a week. The texts chosen for the course consisted of 13 short texts by authors from different countries, including South Africa, the 
United States, South America, and Pakistan. The genres of the short texts included speeches, essays, and letters. The topics covered included heroism, friendship, local culture, love, and ways of life. The course focused on examining the texts' grammar, vocabulary, themes, and organization, and participating in writing, grammar, and reading comprehension activities.

The course's Korean students consisted of females majoring in English education who spoke Korean. Based on initial interviews for background information, none of the students had any prior overseas experience. Among the 29 female students, 11 noted that their first exposure to the English language occurred before entering an elementary school at a private institution.

Most of the students began learning English officially in grade school. The students had taken college courses, such as English presentation skills, American literature, Korean language studies, advanced reading and listening, and English academic writing in pursuit of their undergraduate degrees in English education studies. All of the students had limited prior experience with global literary texts.

\subsection{Exercises}

During their course studies, the native English-speaking teachers became more knowledgeable about global literary texts, and the researcher invited them to build a reading list for the Korean students. The teachers chose English illustrative texts that portrayed global cultures beyond that of the United States. They were conscious of the fact that a single book could distort the students' outlook on culture; however, the reading list served as an invitation for further reading about a specific culture. The researcher also requested the Korean students to recommend a list of global literary texts; however, the students had little knowledge of such texts and were unable to find any interesting texts in English. Therefore, the Korean students chose four texts from the suggested reading list (Table 1).

Table 1. Student-selected global literary texts.

\begin{tabular}{ccccc}
\hline Book & $\begin{array}{c}\text { Content and Portrayed } \\
\text { Culture }\end{array}$ & Author & Illustrator & Student Project \\
\hline $\begin{array}{c}\text { Malala Yousafzai: } \\
\text { Warrior with } \\
\text { Words }\end{array}$ & $\begin{array}{c}\text { Malala is a testament to } \\
\text { the power of education } \\
\text { to change the world for } \\
\text { girls and boys in } \\
\text { Pakistan and } \\
\text { worldwide. }\end{array}$ & $\begin{array}{c}\text { Karen } \\
\text { Abouraya }\end{array}$ & Susan Roth & Create electronic \\
texts & & &
\end{tabular}

Save the Land

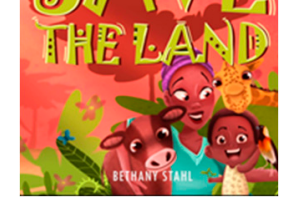

Amari learns about the people of Africa in their effort to fight desertification in Africa.
Bethany Stahl Bethany Stahl

Produce video clips
Mindy Kim and the Lunar New Year Parade

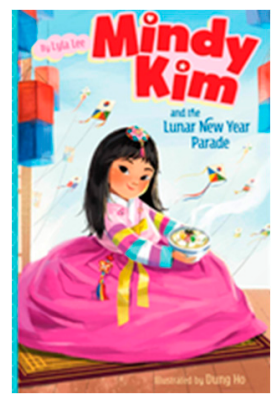

Mindy Kim decides to make traditional Korean New Year food in the U.S. and finds a way to enjoy her old holiday traditions and create new ones along the way. 
Table 1. Cont.

\begin{tabular}{|c|c|c|c|c|c|}
\hline Book & & $\begin{array}{c}\text { Content and Portrayed } \\
\text { Culture }\end{array}$ & Author & Illustrator & Student Project \\
\hline The Royal Bee & $\begin{array}{c}\mathbf{R} \\
\mathbf{O} \\
\mathbf{Y} \\
\mathbf{A} \\
\mathbf{L} \\
\mathbf{B} \\
\mathbf{E} \\
\mathbf{E}\end{array}$ & $\begin{array}{l}\text { Song-ho is a young } \\
\text { Korean destined by birth } \\
\text { to a life of poverty, but } \\
\text { he dreams of learning to } \\
\text { read and write. }\end{array}$ & $\begin{array}{c}\text { Ginger Park } \\
\& \\
\text { Frances Park }\end{array}$ & $\begin{array}{c}\text { Christopher } \\
\text { Zhong-Yu Zhang }\end{array}$ & $\begin{array}{l}\text { Writing about } \\
\text { dreams }\end{array}$ \\
\hline
\end{tabular}

Each week, Dr. Yoo read aloud from one text. The students divided themselves into groups of four or five and discussed the text and shared their understanding of the text and how it might be implemented in the primary school classroom. Then, they discussed their responses in a large group and participated in freewriting. The students proceeded to respond in small groups after the end of classes. Dr. Yoo showed the students how to respond to the prompt (refer to Table 1). In response to the prompt, the students planned and produced short videos about planting trees in Africa for sustaining forest diversity and enlisting support for Africa, after reading Save the Land, by Bethany Stahl. They created electronic texts about Korean female reformers and activists after reading Malala Yousafzai: Warrior with Words, by Karen Abouraya. After reading The Royal Bee, by Ginger and Frances Park, the students wrote about building their dreams and hopes. They also created PowerPoint presentations to present ways of celebrating and sustaining the Korean traditional New Year, after reading Mindy Kim and the Lunar New Year Parade, by Lyla Lee.

One discussion thread involved communication between cross-national groups. The discussions among American native English-speaking teachers about the illustrative texts were recorded by video and asynchronously distributed to the students in Korea. The teachers raised questions for the Korean students through the recorded videos. Such questions included the following:

1. Do all young women in Korea attend school on a regular basis and if so do they attend all-women schools? There is a preconception that Korean young women in the past did not attend school. Was this true? For those who go to school, what happens if they don't pass the high school entrance exam?

2. What are some preconceptions that Koreans have about Americans?

The Korean students viewed the videos in their original formats, addressed the teachers' inquiries, and asked the teachers their own questions in English. Dr. Yoo gathered the students' responses and forwarded them to the group of teachers in the United States. The Korean students inquired about topics such as politics, education, social matters, and family, as noted below:

1. What do parents in the United States think of education in Korea?

2. Do kids become financially independent from their parents after graduating from college? Do the kids take care of their parents when they grow old?

3. What are your expectations from your new president?

\subsection{Data Collection and Analysis}

Primary data for this study included the Korean students' English group discussions. The group discussions were audio-recorded and transcribed verbatim. In addition to the group discussions, the researcher conducted in-depth semi-structured interviews with each of the students (78 interviews in total). The interview topics included ways in which the class exercises informed the students' perceptions of various cultures, progress made after reading the texts, and ways the exercises might have influenced the students' learning of 
the English language, as future English teachers. Each interview lasted between an hour and an hour and forty minutes. All interviews were conducted in English. To further support the interviews and the group discussion data set, secondary data were collected, including observational notes of the group discussions about the literary texts and collected samples of student projects related to the texts.

As is typical in a qualitative study, data collection and analysis did not always take place consecutively. While interviewing the participants, the researcher continued to observe group discussions, have informal conversations with the participants, and analyze the group discussions, interviews, and observational data. Thus, data collection and data analysis reciprocally influenced each other.

The researcher transcribed the recordings and read the transcripts. NVivo-7 was used to facilitate the coding and analysis of the data. Analysis began with line-by-line coding, generating free nodes. Then, the researcher grouped the free nodes of similar features into tree nodes. This process helped to summarize the data and present the key points of the interviewees' responses.

Thereafter, the researcher attempted to create categories that described the connection between tree nodes in a meaningful way to explain the relevant research question (Glaser and Strauss [30]). In this process, some of the categories were redefined and revised. As the researcher continued to integrate and refine the categories, themes that crystallized the relationships between the categories were developed and shared with Dr. Yoo as part of member-checking (Stake [31]). A few themes are presented below as part of the findings, with representative data from the participants.

\section{Findings}

In the findings section, the themes of "self-knowledge," "understanding others," and "English learning" are presented below.

\subsection{Self-Knowledge}

The Korean students reflected on their cultural ways of life and started to think critically about others and themselves while reading the global literary texts and communicating with the native English-speaking teachers.

\subsubsection{Self, Culture, and History}

The Korean students were surprised by the native English-speaking teachers' preconceptions about Korean culture, particularly when the teachers questioned whether young Korean women attended school on a regular basis. The students contended that Korean women today receive equal treatment and achieve success similar to men. Students claimed, "We have equal pay and opportunities," and "Korea is a developed country with a strong IT business and many old features of Korea have changed in [at] a fast pace since the Korean War." A small group of students contemplated and discussed the history of Korea:

Mina: There is [has been] much much change from the old past. In the past, women and girls could not attend school normally like boys. A few women from rich families had a chances [chance] to attend schools for all-girls. [The group of students discussed and shared stories about their grandmothers who had struggled for their rights for education and pursuing their dreams] (group discussion \#14).

Jeeson: A really really long time ago, parents only preferred the birth of boys. Most of them believe[d] a son can grow up and later take care of their parents when the parents become really old. You can see how parents cared much for boys more than girls (group discussion \#14).

Narae: This is truly gender discrimination. It is a shock that people ask if Korean girls can go to school regularly. This is the 21st century! Korean people in ancient times is [were] very small-minded. They believe men could have more rights and could attend school whenever they want. But, as you know, women couldn't freely go to school, so it 
was really unfair back then. I hear [heard] there have been women who have tried to fight for free speech to get an education (group discussion \#14).

The students' reflection on the history and culture of Korea helped them in openly sharing their thoughts and sentiments about young women's roles in Korean society.

Furthermore, after reading Save the Land and Malala Yousafzai: Warrior with Words, the students shared stories about Korean heroines and leaders from the past and the present. As a response to Dr. Yoo's prompt, the students talked about leading female characters in historical and contemporary times, such as Lee Tai-young, the first female lawyer in South Korea; Yuna Kim, the first female figure skater to win at the Olympic Games; Queen Seondeok, who is remembered for the cultural impact she had during her reign; and Yu Gwan-sun, who became a symbol of the country's fight for independence from Japan. The students produced electronic books highlighting female activists they favored most, thereby making connections with influential and progressive women in their culture (see Appendix A, Figure A1). The students reflected on their culture and society after reading texts in English about Korean culture. They raised the question, "It's not easy to find a lot of English books with images and pictures of famous and political leaders for us to read. I have to order the good ones from Amazon. I wonder if I can find more books like that locally here." Korean students typically read prescribed textbooks, short online texts, and classical literature to learn language. While there are various types of authentic texts, students rarely have access to them in the classroom. While the students had never considered global or Korean culture and issues previously, they were curious to learn more about illustrative texts portraying these matters.

In addition to reflecting on the future, the Korean students had hopes for the future. Below is one of the hopes Lia wrote after reading The Royal Bee:

Korea is a very advanced country and because of some painful history with Japan, free speech of people is [a] very important part of our society. A very long time ago, even if [the] education system is [was] controlled by Japan which was not equal for everyone, it is of course now open to everyone and anyone can get [an] education and go to university. I now hope that Korea will be united and all Korean[s] will have the same opportunity for education. (student document \#8)

The Korean students not only contemplated who they were as individuals; they also envisioned who they were evolving into.

\subsubsection{Cultural Reflection}

After reading Mindy Kim and the Lunar New Year Parade, the students became aware that the text reflected a culture from a particular region and household in Korea and could not be generalized to other regional provinces. The students noted that the customs varied between coastal and inner provinces under the umbrella of South Korean culture, and further varied between North and South Korea. This prompted the students' interest in the New Year and Christmas culture in the United States. The students were curious about the details of how people in America perceived the traditional custom of the Korean New Year and their general views of Korea as a country. Recognizing that a single text may only depict a specific regional culture allowed the students to inquire critically about the texts they read about specific customs in America. During the student group discussions, they asked, "Does the book show an authentic image of the U.S. culture? I wonder, is the story true or just a story [fiction]? Does [the] book show a general image of U.S. culture or a specific region?" (group discussion \#17).

The Korean students' reflection prompted further questions. The native Englishspeaking teachers' preconceptions about Korean culture also instigated the students' curiosity of customs and traditions in America. Therefore, the students gathered written questions to ask the teachers. For example, students asked, "Do Americans usually drink a lot of soda at every meal in a restaurant? Is it true that most people in the U.S. are considered overweight so everyone is on [a] diet?" Moreover, the students asked the teachers to 
clarify whether the texts they were reading authentically reflected the culture in America (originally in English, student document \#11).

The students began to inquire about the content of the illustrative texts and wondered if the texts depicted and sustained an authentic culture. One student claimed, "Sometimes what we read and see may be something different from the real truth. So, it is important I think to try hard to understand the real facts" (part of group discussion \#14). Another student added, "This shows us [that] we need to rethink what we read and hear." Dr. Yoo noted that interacting with the native English-speaking teachers and discussing and reflecting on their feedback offered the students first-hand resources and assisted the students in re-addressing and correcting their preconceptions of American culture.

\subsection{Understanding Others}

Through the opportunity to encounter global literary texts, the students learned to respect different cultures, build and sustain global appreciation, and advocate for others.

\subsubsection{Sustaining Global Consciousness}

Through the illustrative texts, the students read various stories and learned about different countries. As the students read texts for the course, they stated that they rarely read anything about the Middle East or South Africa. A student commented in the survey, "It is beneficial to read texts from many countries and their culture because it help[s] me expand my knowledge and perspectives I was not aware of before".

The students read about Malala and gained more knowledge about Malala's country. They noted that they were unaware that there were countries that still suffered under such hazardous circumstances. Through the text, the students learned that young women in Pakistan suffer from gender discrimination and lack equal opportunities for education. As portrayed by Malala, a Pakistani girl stands up and speaks out for every child's right to education. The Korean students believed that Malala stood as a role model for young girls as powerful and courageous.

The Korean students compared the cultural differences among countries. They inquired with the native English-speaking teachers about school culture in the United States, sports, entertainment, family traditions, social matters, and how women fight for their rights. The teachers' questions and comments with respect to the students' inquiries broadened the students' understanding and knowledge. Therefore, the students began to go beyond their local communities and to perceive themselves as members of a larger global community. For example, Miyoung wrote, "There are some parts of their culture I thought I already know but deeply did not know very well. It would be very nice to travel and broaden my perspective when I can interact with them and knowing [know] more about their way of life" (student document \#12).

As set out below, the students in their groups discussed what they learned from reading the four illustrative texts and interacting with the teachers:

Yerin: Some of our thoughts about people in the U.S are [a] little different now. I was prejudiced about [against] Americans; they are generally loud and carry guns everywhere. I know not everyone is like that and they actually seem very nice (group discussion \#16).

Gayoung: I thought most of them were fat and eat [ate] a lot of greasy food. But, these days there are more young women who are slim and healthy (group discussion \#16).

Hanna: I think at first Christianity was [the] main and maybe only accepted religion in the United States, but I read about different kinds of religions [ ... ]. I read how students behave in the classroom and they seem very active in sharing ideas and not feel conscious about themselves (group discussion \#16).

Jiyoun: I know [knew] before they did a lot of discussion and debate in class; how they initiate it and try to persuading [persuade] other people was kind of interesting (group discussion \#16). 
The Korean students gradually learned to become more cognizant of their preconceptions and achieved a new understanding of American culture through their communications with the native English-speaking teachers from the United States.

\subsubsection{Appreciation and Compassion}

The students gained an appreciation for the various cultures around the world and showed compassion for people who endured injustice and destitution in Middle Eastern and South African countries. For example, one student noted, "Every culture has [their] own distinct feature[s] and history. Sometimes it is difficult for me to imagine the real story, but it pushes me to appreciate it" (group discussion \#17). After reading Save the Land, Joohee noted,

Globally, we hear about the bad health situations in Africa, but I thought it was getting [a] little better because many volunteers help them. I did not realize life can be depressing without the basics in [sic] having water to make the land fertile [... ]. If I had time, I think it is a good opportunity to help with water management and show the local community [how] to use their sources for some kind of alternative method. (student document \#13)

Many of Joohee's colleagues reiterated these sentiments in the group discussions and in their writing. Dr. Yoo noted that she was impressed with the students' empathy towards the situation in Africa and the African people and with the students' commitment to take measures to help people in the African continent. She noted that "the students felt there could be something they could do to let more people know about the desertification in Africa [ ... ] they were questioning why there were no local policies to sustain land management to prevent poverty" (part of group discussion \#18).

The students gave thought to the situations of other people and reflected upon their own lives.

Hana wrote, "I don't think I ever have to think about our land becoming dry and not have of water [ ... I I feel we should be more active and let our friends know about saving water and our ecosystem. First, we can try to imagine what it can [would] be like to live like them with no rich land to grow food and crop[s]" (student document \#10)

During class time, the students discussed the importance of appreciating the opportunity for education, having plenty of water, and having other basic amenities in life. When Dr. Yoo provided the response prompt of a short video, the students brainstormed, then designed and produced a clip promoting a message about preserving water on their local school campus and shared their final project with their colleagues. Reading to take action displayed the expansion of the students' critical thinking in raising awareness.

\subsubsection{Raising Awareness}

The students began to take further responsibility to become global citizens. After reading Save the Land, many of the students wished to volunteer and take more actions beyond their local society, to include the global community. Sunhye wrote, "There is a UN website about awareness of African's desertification. We can begin to give some money to help. We hear about the term, glocalization. This means the local is part of the global, so I think we need to help make change with global problems too" (student document \#17). Dr. Yoo shared that "I think the Korean students are able to further broaden their own understanding of world culture and learn to view social issues from a critical stance from reading the texts. It even influenced what they hoped for in the future on some social matters" (part of group discussion \#16).

In addition to volunteer work, the students began to share ideas on how to voice equal rights in contemporary society. The students believed that one individual could make a small difference in the world. One student wrote, "We can't make [a] big change, but one person can begin to take step[s] to help others because this will accumulate and make bigger changes in the future" (student document \#11). Adding to this, Soyoung noted: 
The world has advanced very quickly, but it is also not very stable and not equal for everyone. If we give our attention to other countries' situation[s], we can see [that] not all the [sic] people have [the] same luxury of free water and rich land for farming. Even in the situation in Korea, when we consider the environment, it is getting worse and the government is making hydrogen car to make changes. Like this, we should take responsibility too. And, when we think of Africa and their situation, it remind[s] us we should not waste our water and be thankful for our fertile land and think about countries with problems in their environment [ . . . When we read more about Malala, it is difficult to imagine not having [the] same education opportunity. It makes me think how I can help them have the same opportunities as me. (student document \#15)

Moreover, Jina hoped as follows: "The problem in the world cannot be solved in one day or one generation. But, if we have some small interest it can help. There are many people we don't know about who try to help others and I hope I can be part of that" (group discussion \#16). What can be speculated from the student responses is that the global illustrative texts encouraged the students to support more resources and to advocate for equal rights across the globe.

\subsection{English Learning}

As the students gained more interest in global illustrative texts, they developed their English language competency by reading the global texts and interacting with the native English-speaking teachers.

\subsubsection{Sustaining Student Involvement}

The subject matter of the texts, the represented cultures, and the interactions with the native English-speaking teachers sparked the students' curiosity and motivated them to think critically and reflect on the readings. Overall, the students appreciated the list of global texts and disclosed in the survey that they wanted time in class to read and discuss more global texts and to have authentic opportunities to respond to the texts.

As the students read the list of illustrative texts, they alternated between informative and aesthetic viewpoints. As learners of English, the students often perceived reading texts in English for informative purposes. From the illustrative texts, the students valued gaining and sustaining new cultural and linguistic knowledge; however, as seen in the previous student responses, they did not approach the texts only for informative purposes, but they also appreciated reading about and discussing social and cultural issues from the texts.

\subsubsection{Language Knowledge}

The Korean students continued to build and sustain their English skills through reading the texts, interacting with the native English-speaking teachers, and interacting with their colleagues. As one student stated, "Learning English expressions and new words was helpful for me and also when I teach, but I learn more through the different kinds of cultures" (group discussion \#14). It was through the cultural context from the readings that the students built their English skills.

In addition, the students noted that they learned authentic expressions and new vocabulary. During group conversations, the students shared that they found interesting verb- and noun-usage in words and expressions such as savannah, seedling, tuck, sapling, tree line, sway, and gobble in Save the Land. A student noted, "Most words I already heard before, but I never think [thought] about how it can be used in [a] particular context. It will be useful to apply how they use it in the story" (group discussion \#14).

The students also built their skills in writing and reading. Dr. Yoo and the students noted that the students' language skills strengthened as the instructor read aloud from the texts and the students read and shared ideas in their groups. The diverse and authentic means to address the readings, the student group discussions, and the communications with the native English-speaking teachers assisted the students in determining meaning, challenging the writers of the texts, and critically reflecting on their understandings. 
Through these practices, the students gained more opportunities to practice and learn English in an authentic manner.

The students noted that such opportunities assisted in their writing practices. They performed freewriting and reshaped their writing in their electronic texts and power point presentations. They made use of the four illustrative texts as mentor texts; for example, they created electronic texts about female activists such as Malala. One student, Boyoung, used The Royal Bee as her mentor text and structured her own writing into subsections similar to those in the original text. On the other hand, Eunice included a collage of photos in her writing, without a prompt, and reconstructed a multimodal product (Figure 1).
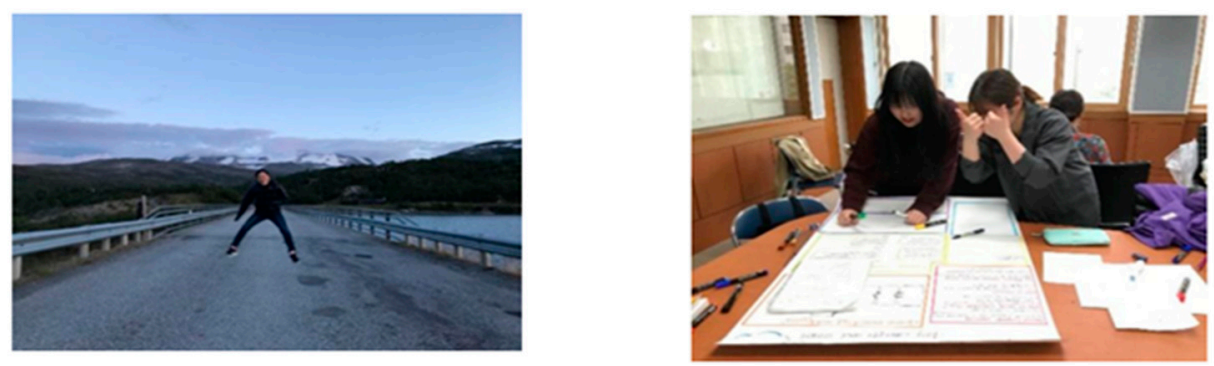

Wherever we go, people are connected in some aspects. As a major in English Education, I want to continue to communicate in English with my colleagues to share knowledge. I also find it important to travel more and see the world to widen my perspective to many cultures around the world. After the COVID, I plan to make some future plans for traveling and to make proactive changes globally. One important plan is to read more books about other countries in more detail and share my understanding in a deeper way. This way, I can begin then to make more specific plans about the future step by step.

Figure 1. Example of student writing.

\section{Discussion}

In this current research, the Korean learners of English acquired more reader responsibilities, began to appreciate various cultures by reading global illustrative texts and engaging with the native English-speaking teachers, and cultivated deeper intercultural awareness. The instructor, Dr. Yoo, went beyond the four texts to present new literary texts, guided the students in contrasting and comparing their own culture and those of others, encouraged student discussion and design of authentic activities, and inspired the students to develop global networks and present themselves as global citizens.

The students' concept of intercultural awareness developed from an awareness to acknowledgement and appreciation; the students gradually built competence in intercultural understanding. Their responses, inquiries, and interactions with native English-speaking teachers shifted from knowing about one another's families, political views, hobbies, academic backgrounds, and social problems to redressing preconceptions and misconceptions. They grew more concerned as to whether the texts they read accurately reflected the target culture and whether their interactions altered the native English-speaking teachers' preconceptions of Korean culture. The students evaluated and practiced critical analysis of the readings. This overall experience encouraged them to consider social measures on global issues.

Through the window of the illustrative texts, the students gained and sustained more knowledge about various cultures and reflected on themselves as individuals. They were cognizant of a number of similarities between the cultures of Korea and the United 
States; for instance, regardless of gender, everyone had the same opportunities for higher education, scholarships were widely available for students, and both cultures held family values and education in high regard. The students valued the opportunity to gain accurate cultural knowledge from the native English-speaking teachers and the authentic texts. Rather than relying on their instructor and passively searching for answers provided through online search engines, the students developed more autonomous learning and critical thinking. Their communications with the native English-speaking teachers further motivated the students' in-depth thinking and encouraged them to take initiatives on social issues.

An additional feature was that the students began to shift from the in-your-head model of reading to a cultural-context model. The students were able to sustain more responsibility through communicating with native English-speaking teachers in a global context, with colleagues in their own cultural environment, and through reading the texts. They grew more critical of the readings and started to raise more questions. The students questioned whether the illustrative texts correctly reflected the cultures depicted in them, and critically analyzed the writers, the texts, and themselves.

Finally, the students' responses and communications with the native English-speaking teachers, and among the students internally, encouraged them to learn and acquire language skills through authentic tasks in social contexts. The students read the texts to gain knowledge of and appreciation for other cultures. They needed knowledge about global cultures and issues to promote critical viewpoints and they hoped to take more steps to learn about various cultures. The illustrative texts and discussions motivated the students to think as part of a global community and to take more responsibilities as readers.

\section{Conclusions and Limitations}

A major limitation of the current study is that the findings cannot be generalized to other student populations from majors other than English. The researcher believes it is possible to adjust the suggested approach to students who are not majoring in English. While member-checking was administered with the instructor, the findings were contingent on the researcher's interpretations. Moreover, the student responses may be biased, as their responses may have been presented to please the instructor and the researcher. Perhaps having a researcher with a different relationship or standing with the students could have resulted in different outcomes.

Despite such limitations, the researcher recommends that teachers introduce global literary texts and build an intercultural syllabus to link students to the global world. A few steps can be taken for English language and literacy teachers when introducing global illustrative texts to build students' intercultural understanding. To begin with, teachers could gather a list of global illustrative texts from online sources or the local library and request the aid of a cultural insider to review the list of texts. It might be wise to choose a list of texts from a single culture to prevent preconceptions from the representation of a single text. Next, teachers may invite students to read the texts out loud and initiate discussions about them. Then, to respond to the texts, the teachers could provide a space for the student groups to converse about the texts, practice freewriting, make presentations, and create electronic books. Finally, it might be helpful to build a larger community by inviting students from different grade levels and schools to participate in a virtual book club.

Additional selections of books about diverse cultures could help readers strengthen their understanding of cultures and foster different points of view. Both the Korean students and the instructor hoped to further interact with native English-speaking teachers and learn more about other cultures in the United States. Further communication could occur between American college students and Korean college students from different grade levels and ages, or college students from both countries could converse. Maintaining continued communication across such groups can foster a more critical stance towards global literary texts and a broader cultural understanding. Additionally, teachers may assist students of all ages in creating multimodal texts to expand their views of the world. 
Thus, an intercultural curriculum framework would promote critical inquiries and build global-oriented students. Reading global illustrative texts in the classroom helped EFL learners strengthen their language abilities, cultivate their critical thinking skills, and stimulate their intercultural awareness.

Funding: This work was supported by the "Research Base Construction Fund Support Program" funded by Jeonbuk National University in 2021.

Institutional Review Board Statement: .IRB no. CDE13001; Approval date: 22 February 2021; Ethics Committee: Chairman of the Research Ethics Review Committee; “This projects meets the exemption criteria for federal regulation 46.101(b)1 for research involving normal educational issues within an educational environment and where the identity of the participant is protected. It also meets the exemption criteria for federal regulation 46.101(b)2 for research involving normal interviews where the identity of participant is being protected".

Informed Consent Statement: Informed consent was obtained from all subjects involved in the study.

Data Availability Statement: The data presented in this study are available on request from the author.

Conflicts of Interest: The author declares no conflict of interest.

\section{Appendix A}

Sample student electronic text.

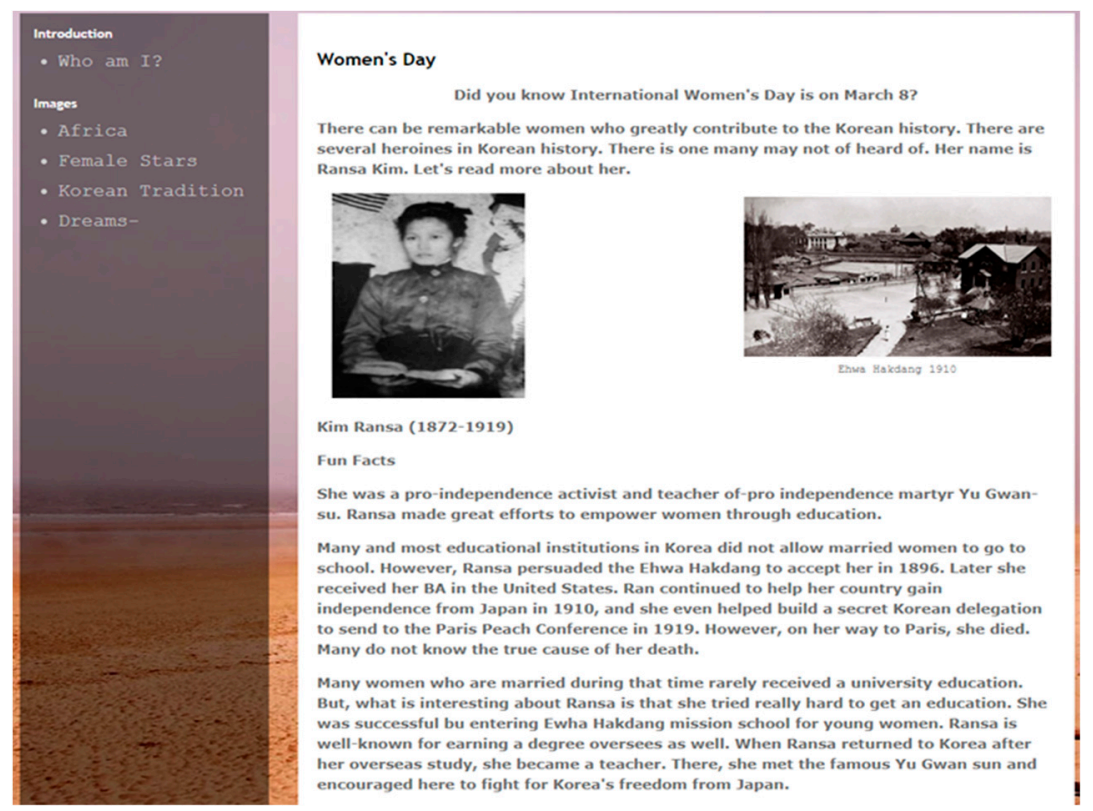

Figure A1. History of Kim Ransa.

\section{References}

1. Korean Ministry of Education. The 2015 Revised Curriculum. Available online: http:/ / english.moe.go.kr/sub/info.do?m=0401 $01 \& s=$ english (accessed on 14 March 2021).

2. Lee, Y.; Villacorta, P. An analysis of the needs of Korean EFL learners in the collegiate level. J. Arts Humanit. 2017, 6, 15-24. [CrossRef]

3. Freire, P. Education for Critical Consciousness; Seabury Press: New York, NY, USA, 2005.

4. Rosenblatt, L. Making Meaning with Texts: Selected Essays; Heinemann Press: Portsmouth, NH, USA, 2005.

5. Kang, H. Linking task-based language teaching and assessment: Practices and possibilities. Stud. Engl. Educ. 2018, 23, 891-915. [CrossRef]

6. Kim, N. Teachers' perspectives on content-based instruction in English at a higher education in Korea. Engl. Teach. Assoc. Korea 2012, 18, 91-114.

7. Peck, C.; Yates, L. Negotiating intercultural experience through English as a foreign language in South Korea. Lang. Intercult. Commun. 2019, 19, 51-63. [CrossRef] 
8. Kim, Y.; Jung, Y.; Tracy-Ventura, N. Implementation of a localized task-based course in an EFL context: A Study of students' evolving perceptions. TESOL Q. 2017, 51, 632-660. [CrossRef]

9. Evans, A.; Wilson, C. Linking attainment to interculturalism and global citizenship. In Student Attainment in Higher Education: Issues, Controversies and Debates; Stevenson, G., Cureton, L., Clouder, L., Eds.; Routledge: Oxford, UK, 2016 ; pp. 54-66.

10. Flynn, J. Speaking up and speaking out? Long-term impact of critical multicultural pedagogy. Multicult. Perspect. 2017, 19, 207-214.

11. Short, K.; Thomas, L. Developing intercultural understandings through global children's literature. In Reclaiming Reading: Teachers, Students, Researchers Regaining Spaces for Thinking and Action; Meyer, R., Whitmore, K., Eds.; Routledge: Oxford, UK, 2012; pp. 149-162.

12. Hong, W. Multicultural education in Korea: Its development, remaining issues, and global implications. Asia Pacific Educ. Rev. 2010, 11, 387-395. [CrossRef]

13. Huang, C.M. Fashion or compensation: The developments of multicultural education in Taiwan. In Global Construction of Multicultural Education: Theories and Practices; Grant, C., Lei, J., Eds.; Erlbaum: New York, NY, USA, $2001 ;$ p. 115.

14. Mo, K.W.; Hwang, H.W. Social studies teachers' perception of multicultural education and its implications on teacher education programs. J. Korean Teach. Educ. 2007, 24, 199-219.

15. Otten, M. Intercultural learning and diversity in higher education. J. Stud. Int. Educ. 2003, 7, 12-26. [CrossRef]

16. RodrÃ-guez, L.; Puyal, M. Promoting intercultural competence through literature in clil contexts. Atlantis 2012, 34, 105-124.

17. Heggerness, S. Opening a dialogic space: Intercultural learning through picture books. CLELE J. 2019, 7, 37-60.

18. Briceño, A.; Klein, A. A second lens on formative reading assessment with multilingual students. Read. Teach. 2018, 72, 611-621. [CrossRef]

19. Yol, O.; Yoon, B.G. Engaging English language learners with critical global literacies during the pull-out: Instructional framework. TESOL J. 2019, 11, e470. [CrossRef]

20. Yokota, J.; Teale, W. Striving for international understanding through literature. Read. Teach. 2017, 70, 629-633. [CrossRef]

21. Heath, S. Ways with Words: Language, Life, and Work in Communities and Classrooms; Cambridge UP: Cambridge, UK, 1983.

22. Comber, B.; Nixon, H. Critical literacy across the curriculum: Learning to read, question, and rewrite designs. In Moving Critical Literacies Forward: A New Look at Praxis Across Contexts; Pandya, J., Avila, J., Eds.; Routledge: Oxford, UK, 2014 ; pp. 83-97.

23. Yoon, B. Critical literacies: Global and Multicultural Perspectives; Springer: New York, NY, USA, 2016.

24. Dasli, M. Reviving the 'moments': From cultural awareness and cross-cultural mediation to critical intercultural language pedagogy. Pedagog. Cult. Soc. 2011, 19, 21-39. [CrossRef]

25. Cope, B.; Kalantzis, M. "Multiliteracies": New literacies, new learning. Pedagog. Int. J. 2009, 4, 164-195. [CrossRef]

26. Floyd, C.B. Critical thinking in a second language. High. Educ. Res. Dev. 2011, 30, 289-302. [CrossRef]

27. Hedgecock, J.; Ferris, D. Teaching Readers of English; Routledge: Oxford, UK, 2009.

28. Larson, J.; Marsh, J. Making Literacy Real: Theories and Practices for Learning and Teaching; Sage: Los Angeles, CA, USA, 2014.

29. Vygotsky, L. Thought and Language; MIT Press: Cambridge, MA, USA, 1965.

30. Glaser, B.G.; Strauss, A.L. The Discovery of Grounded Theory: Strategies for Qualitative Research; Routledge: London, UK, 1999.

31. Stake, R. The Art of Case Study Research; Sage: Los Angeles, CA, USA, 1995. 